\title{
The Influence of Tourist Motivation on Revisit Intention to Alas Harum Agro tourism of Gianyar Regency, Bali
}

\author{
Pebrianita Ivana Karo Sekali ${ }^{1}$, \\ I Gusti Ayu Oka Suryawardani ${ }^{2}$, Ratna Komala Dewi ${ }^{1}$ \\ ${ }^{1}$ Agribusiness Study Program, Faculty of Agriculture, Udayana University \\ ${ }^{2}$ Centre of Excellence in Tourism, Udayana University \\ Corresponding Author: pebri.ivana@gmail.com
}

\section{ARTICLE INFO}

Received

20 August 2020

Accepted

3 September 2020

Available online 30 September 2020

\section{ABSTRACT}

The positive perception of tourists about tourist attraction will give satisfaction to tourists which in turn will create intention to revisit. This study aims to analyze the influence of motivation (intrinsic and extrinsic) on the tourists' satisfaction of Alas Harum Agrotourism, and analyze the effect of tourist satisfaction to revisit intention. The purpose of this study is also to evaluate the contribution of Alas Harum Agrotourism to the welfare of the community and surrounding farming families. The research data was processed in quantitative data using the Smart-PLS version 3.0 program and qualitative data was processed with descriptive analysis. The number of respondents in this study was 50 respondents. The results showed that intrinsic and extrinsic motivation had a significant effect on tourist satisfaction $(P=0,000)$. Tourist satisfaction has a significant effect on revisit intention $(P=0,000)$. The results also showed that Alas Harum Agrotourism contributed both to the community and surrounding farmers. Based on the results of the study, it is expected that Alas Harum Agro tourism can improve the quality of services and be able to maintain the beauty of nature to increase the motivation of tourists, that are having good results already.

Keywords: tourist motivation, visitor satisfaction, revisit intention, partial least square

\section{INTRODUCTION}

\section{Background}

According to Sutjipta (2001), agrotourism can be defined as an integrated and coordinated system of activities for tourism development as well as agriculture, in relation to environmental preservation and http://ojs.unud.ac.id/index.php/eot improvement of the welfare of the farming community. People's preferences and motivations tend to lead to fulfillment of needs in the form of enjoying specific objects such as beautiful natural scenery, cool air, and processing of various kinds of agricultural products, both traditional and modern.

e-ISSN: 2407-392X. p-ISSN: 2541-0857 
This has an impact on shifting the consumption patterns of tourists who are "back to nature", this is a sign as well as an opportunity for the development of agrotourism either in the form of an area that offers natural scenery and fresh air or in the form of agribusiness products and their processed products. Suryawardani's (2016) research results regarding the calculation of Bali tourism leakage found that the average amount of leakage in Bali tourism from the accommodation sector was $20 \%$ and the highest leakage was in star hotels which are chain hotels $(53.3 \%)$.

The results also found that the source of the leak was the use of imported drinks (64.1\%), imported food (20\%) and foreign workers $(2.1 \%)$. So, what is done to minimize the leak is to optimize the potential for tourist attraction based on Bali's nature and culture. The tourist attraction based on Bali's nature and culture is agrotourism. One of the popular agrotourism among tourists is Alas Harum Agrotourism. The development of tourism in a tourist attraction is considered good if the tourist attraction is managed appropriately and can maintain the tourist attraction to become a sustainable agrotourism.

Alas Harum Agrotourism needs to look at the competitive conditions of agrotourism in the future, in order to protect the company's market share from the threat of http://ojs.unud.ac.id/index.php/eot other competitor conditions. This condition underlies the need for studies or research to optimize the existing potential to realize the motivation of tourists to achieve their goals, namely satisfaction. The realization of tourist motivation will have an impact on the satisfaction of traveling for tourists who visit because their goals have been achieved, as well as efforts made to increase tourist visits, which will have an impact on the revisit intention of these tourists. Based on this, the tourist attraction of Alas Harum Agrotourism is a worthy object to be researched, especially regarding the influence of tourist motivation, tourist satisfaction, revisit intention, and the contribution of Alas Harum Agrotourism to the surrounding community and farmers.

\section{Research Questions}

Based on the above background, the research questions that can be raised in this study are (1) How does motivation (intrinsic and extrinsic) influence tourist satisfaction at Alas Harum Agrotourism? (2) How is the influence of tourist satisfaction on tourists' revisit intention to Alas Harum Agrotourism? (3) What is the contribution of Alas Harum Agrotourism to the welfare of the community and surrounding farming families in supporting sustainable agro-tourism?

e-ISSN: 2407-392X. p-ISSN: 2541-0857 


\section{Research Objectives}

Based on research questions, the objectives to be achieved in this study are (1) to analyze the influence of motivation (intrinsic and extrinsic) on tourist satisfaction at Alas Harum Agrotourism, (2) to analyze the effect of tourist satisfaction on tourists' revisit intention to Alas Harum Agrotourism, (2) 3) to evaluate the contribution of Alas Harum Agrotourism to the welfare of the local community and farmer families in supporting sustainable agro-tourism.

\section{Scope of Research}

The scope of research focuses on tourists who visit Alas Harum Agrotourism. This research is limited to assessing the motivation (intrinsic and extrinsic) of tourists on the satisfaction of tourists in Alas Harum Agrotourism in forming revisit intention and evaluating the contribution of Alas Harum Agrotourism to the welfare of the local community and farming families in supporting sustainable agro-tourism. The analytical method used in this research includes quantitative data processed using the Structural Equation Model (SEM) analysis alternative method with PLS (Partial Least Square) using the Smart-PLS 3.0 software program. While the qualitative data was processed using descriptive analysis to obtain an overview of tourist characteristics, information about
Alas Harum Agrotourism, and the contribution of Alas Harum Agrotourism to the welfare of the local people and farming families.

\section{METHODOLOGY}

\section{Research Site and Time}

This research was conducted at the tourist attraction of Alas Harum Agrotourism in Tegallalang Village, Gianyar Regency, Bali. The research was conducted for three months from March to May 2019. Alas Harum Agrotourism was chosen as the location of the research carried out purposively based on certain considerations, including Alas Harum Agrotourism, which is one of the agrotourism in the Tegallalang area which is crowded with tourists and there have never been any researchers who conducted research in agrotourism regarding the analysis of tourist motivation on revisit intention.

\section{Types and Sources of Data}

The types of data collected for this research are quantitative data and qualitative data. The quantitative data of this research are the answers to the quantitative questionnaire statements from Alas Harum Agrotourism tourists, tourist motivation, tourist satisfaction, and revisit intention. The qualitative data of this 
research are in the form of names and addresses of research objects, history of Alas Harum Agrotourism, organizational structure, job descriptions of each section in Alas Harum Agrotourism, and Alas Harum Agrotourism's contribution to the welfare of the community and farmers. Based on data resources used in this study are primary data and secondary data. Primary data is data made by researchers for the specific purpose of solving the problem at hand. Respondent data were collected by the researcher directly from the first source or the place where the object of research was carried out by interviewing and filling out a questionnaire. Secondary data includes literature, articles, journals, and sites on the internet relating to the research conducted.

\section{Method of Collecting Data}

There are several methods used in collecting the research data, namely, filling out questionnaires and interviews with tourists at Alas Harum Agrotourism, interviews with Alas Harum Agrotourism management, heads of Tegallalang Village, farmers, and the local community. Direct observation in the Alas Harum Agrotourism area to see directly the activities of tourists and agro-tourism management. Literature review, by reading books, literature, similar research results, and other media related to the problem under study by collecting written sources and relevant data.

\section{Population and Sample of Research}

The population taken by the researcher is Alas Harum Agrotourism tourists who have visited Alas Harum Agrotourism and are still in the research location. Determination of the number of samples in this study was determined by a non-probability sampling technique by means of purposive sampling, namely the sampling technique with certain considerations or deliberately (Sugiyono, 2015). The sample used in this study amounted to 50 respondents, with the consideration that this number has met the minimum requirements of 30 and a maximum of 100 samples for the SEM analysis method based on the smart-PLS program, with a sample size of 50, which means that it meets the minimum sample requirements of smartPLS.

\section{Research Variables and Measurements}

The variables used in this study are latent variables, namely unmeasured variables. The way to measure these variables is to use indicators to reflect their role as indicators so that the variables can be measured. The types of variables in this study are distinguished as follows; (1) Affecting Latent variables are latent variables that affect other latent variables,

(2) Affected latent variables are latent e-ISSN: 2407-392X. p-ISSN: 2541-0857 
variables that are influenced by other latent variables.

\section{Research Instruments and Measurement Scale}

The instrument in this study was structured, meaning that each question had an alternative answer. Alternative answers using a Likert scale. In the Likert scale, the variables to be measured are translated into variable indicators. This assessment has an alternative answer using a scale of 1 to 5 , with the terms of each assessment.

\section{Data analysis}

The data obtained were processed quantitatively and qualitatively. Quantitative data were processed using the Smart-PLS version 3.0 program to analyze the influence of tourist motivation on tourist satisfaction and the effect of tourist satisfaction on revisit intention. Qualitative data is processed with descriptive analysis to evaluate the contribution of Alas Harum Agrotourism to the welfare of the community and surrounding farming families in supporting sustainable agrotourism, analyzing the description of tourist characteristics, and information about Alas Harum Agrotourism. Smart-PLS has two measurement models in its analysis, namely; (a) Evaluation Analysis of the Measurement Model (Outer Model), (b) Evaluation Analysis of the Structural Model (Inner Model).

\section{RESULTS AND DISCUSSION}

\section{Respondent Characteristics}

Respondents in this study were 50 people who were determined through a non-probability sampling technique by means of purposive sampling. The general characteristics of respondents in this study were analyzed based on country / city of origin, gender, age, occupation, level of education, with whom to come to Bali, visits to Bali, the main purpose of visiting Bali, and the type of activities they prefer to visit in Bali.

\section{Results of the Measurement Model Analysis (Outer Model)}

1. The results of the evaluation of convergent validity

Evaluation of convergent validity begins by looking at the item's reliability (validity indicator) which is indicated by the loading factor value. According to Ghozali (2014), the value of loading factor is considered sufficient if the justification of an indicator to its latent variable is at least 0.7. All loading factor values on each indicator in the study have a value greater than 0.7. This shows that all indicators are valid in measuring variables, so that they can be used in research.

The construct reliability test is evaluated by looking at the value of Composite Reliability or Cronbach's Alpha. The Cronbach's Alpha value on all e-ISSN: 2407-392X. p-ISSN: 2541-0857 
variables is more than 0.7 and the Composite Reliability value on all variables is also more than 0.7. This shows that the variable is said to be reliable. The variable has a convergent value of good validity if the AVE (Average Variance Extracted) value is greater than 0.5 .

Table 1. Cronbach's Alpha, Composite Reliability and AVE scores

\begin{tabular}{lccc}
\hline \multicolumn{1}{c}{ Variable } & Cronbach's Alpha & Composite Reliability & AVE \\
\hline Intrinsic Motivation & 0,919 & 0,935 & 0,675 \\
Extrinsic Motivation & 0,945 & 0,954 & 0,724 \\
Tourist Satisfaction & 0,965 & 0,969 & 0,759 \\
Revisit Intention & 0,912 & 0,938 & 0,792 \\
\hline
\end{tabular}

AVE value for each variable is above 0.5 . This shows that the variable is able to explain more than half of the variance derived from its indicators.

2. Results of the evaluation of discriminant validity

Test the discriminant validity at the variable level by comparing the root of the
AVE value of a variable with other variables. These criteria are based on Fornell-Larcker, where the AVE root value of each variable is greater than the correlation value of a variable with other variables (Fornell and Larcker, 1981 in Santoso, 2018).

Table 2. Fornell-Lacker criteria

\begin{tabular}{lcccc}
\hline \multicolumn{1}{c}{ Latent Variables } & $\begin{array}{c}\text { Extrinsic } \\
\text { Motivation }\end{array}$ & Intrinsic Motivation & $\begin{array}{c}\text { Tourist } \\
\text { Satisfaction }\end{array}$ & $\begin{array}{c}\text { Revisit } \\
\text { Intention }\end{array}$ \\
\hline Extrinsic Motivation & 0,851 & & & \\
Intrinsic Motivation & 0,683 & 0,821 & & \\
Tourist Satisfaction & 0,835 & 0,817 & 0,871 & \\
Revisit Intention & 0,758 & 0,658 & 0,870 & 0,890 \\
\hline
\end{tabular}

The correlation between latent variables itself is higher than other variables. This shows that all latent variables have good validity.
Table 3. AVE Value and AVE Root

\begin{tabular}{lcc}
\hline \multicolumn{1}{c}{ Construct } & AVE & $\sqrt{\text { AVE }}$ \\
\hline Intrinsic Motivation & 0,675 & 0,821 \\
Extrinsic Motivation & 0,724 & 0,850 \\
Tourist Satisfaction & 0,759 & 0,871 \\
Revisit Intention & 0,792 & 0,889 \\
\hline
\end{tabular}


The root value of AVE on all variables is greater than the correlation between variables and other variables. This shows that all latent variables have good validity.

\section{Results of the Structural Model Analysis (Inner Model)}

The model in this study is intended to see the effect of border motivation on revisit intention to Alas Harum Agrotourism through structural equation modeling (SEM) to obtain the best model. Based on the model framework and hypotheses in this study, the following is a structural equation model.

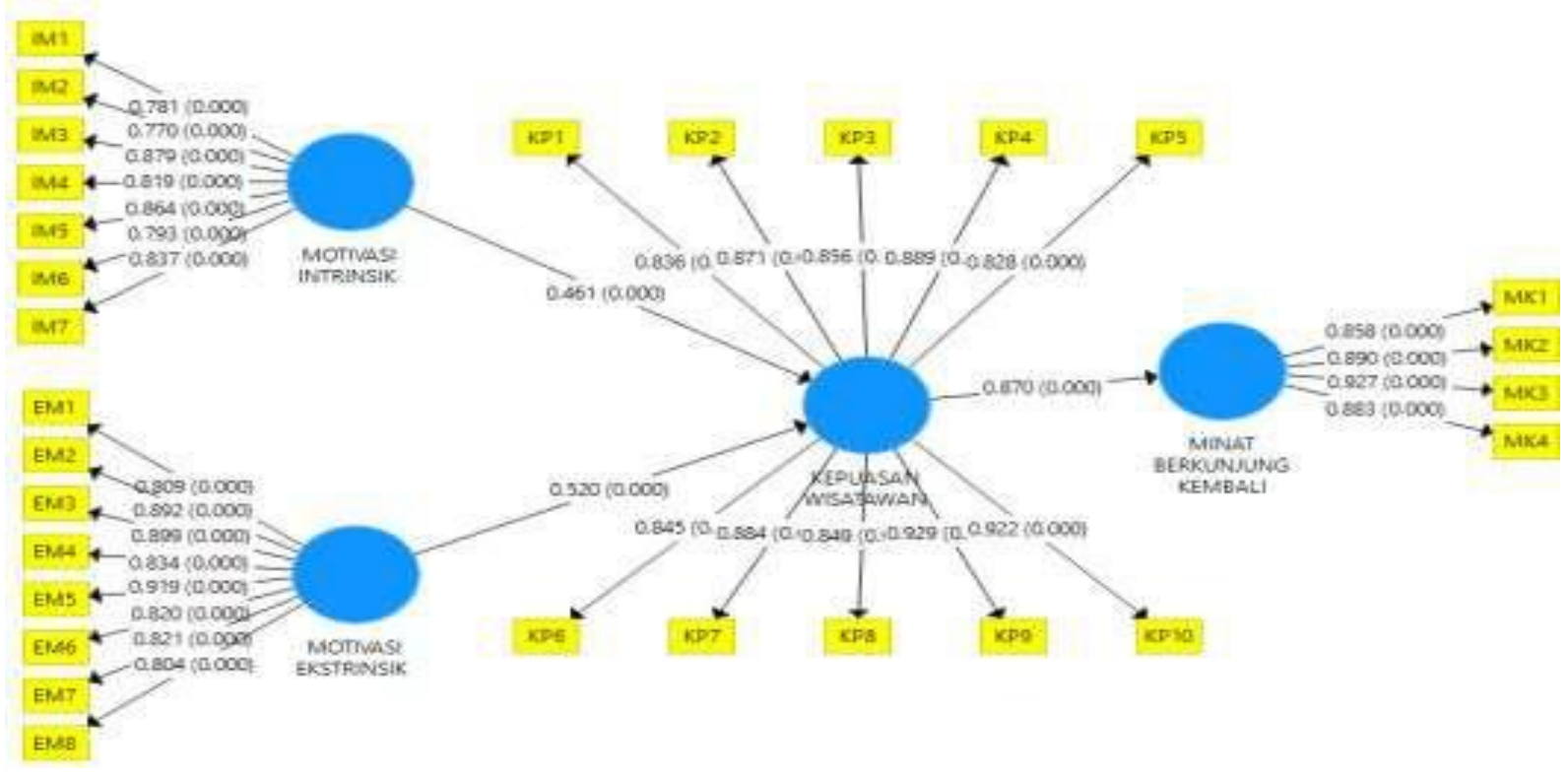

Figure 1. Smart PLS 3.0 based Structural Equation Model Output

1. R square (R2) Test

Table 4. R square Score

\begin{tabular}{ll}
\hline & R square \\
\hline Tourist & 0,819 \\
Satisfaction & \\
Revisit Intention & 0,758 \\
\hline
\end{tabular}

The value of $\mathrm{R}^{2}$ on the tourist satisfaction variable and interest in visiting again has strong predictive power because the $\mathrm{R} 2$ value is above 0.75 (Henseller et.al., 2009 in Santoso, 2018).
2. Test of Godness of Fit (GoF)

Table 5. Fit Model Test Results

\begin{tabular}{ccc}
\hline & $\begin{array}{c}\text { Saturated } \\
\text { Model }\end{array}$ & $\begin{array}{c}\text { Estimated } \\
\text { Model }\end{array}$ \\
\hline SRMR & 0,070 & 0,071 \\
Chin-Square & 648,278 & 650,585 \\
NFI & 0,673 & 0,672 \\
\hline
\end{tabular}

The SMRM (Standardized Root Mean Residual) value, namely the structural equation model, is declared to e-ISSN: 2407-392X. p-ISSN: 2541-0857 
have met the GoF criteria or is said to be feasible if the SRMR value is $<0.10$, the Chin-Square value $\geq 0.05$, and the NFI (Normed Fit Index) value> 0.5. The SRMR (Standardized Root Mean Residual) value, the Chin-Square value, the NFI (Normed Fit Index) value have met certain requirements, so this model indicates a good model or is declared fit and reliable to be used to test the hypothesis.

\section{Hypothesis Test}

The significance of the estimated parameters provides very useful information about the relationship between the research variables. The basis used in testing the hypothesis is the value in the Path Coefficients. Table 4.11 provides the estimated output for testing the structural model.

Table 6. Path Coefficients

\begin{tabular}{|c|c|c|c|c|c|}
\hline & & $\begin{array}{l}\text { Original } \\
\text { sample }\end{array}$ & $\begin{array}{c}\text { Sample } \\
\text { Mean }\end{array}$ & $\begin{array}{l}\text { Standard } \\
\text { Deviation }\end{array}$ & $\mathrm{P}$ values \\
\hline Intrinsic Motivation & $\Rightarrow$ Tourist Satisfaction & 0,461 & 0,464 & 0,079 & 0,000 \\
\hline Extrinsic Motivation & $\Rightarrow$ Tourist Satisfaction & 0,520 & 0,516 & 0,081 & 0,000 \\
\hline Tourist Satisfaction & $\Rightarrow$ Revisit Intention & 0,870 & 0,866 & 0,050 & 0,000 \\
\hline
\end{tabular}

1. The Influence of Intrinsic Motivation on Tourist Satisfaction

The results of testing the first hypothesis indicate that the relationship between the intrinsic motivation variable and the tourist satisfaction variable has a $\mathrm{P}$ value of 0,000 . P-value $<0.05$, then $\mathrm{H} 0$ is rejected. These results indicate that the intrinsic motivation variable has a positive and significant relationship to the tourist satisfaction variable. Thus, Ha in this study is accepted, meaning that in this study the intrinsic motivation variable with its indicators has a significant effect on the tourist satisfaction variable.
The most significant indicator that plays a role is that the concept of enjoying nature will get better inspiration about positive things (IM3) with a loading factor value of 0.879 and a p-value of 0.000 . Indicators that have a low significant value are getting away from a tedious routine (IM2) with a loading factor value of 0.770 and the p-value of 0.000 . The results of this analysis support the research results of Suryawardani et. al (2017), which states that intrinsic motivation has a significant effect on tourist satisfaction in visiting nature-based tourism in Bali. 
2. The effect of extrinsic motivation on tourist satisfaction.

The results of testing the second hypothesis show that the relationship between extrinsic motivation and tourist satisfaction has a $\mathrm{P}$ value of 0.000 . $\mathrm{P}$ value $<0.05$, then $\mathrm{H} 0$ is rejected. The results show that extrinsic motivation has a positive and significant relationship to tourist satisfaction. Thus, $\mathrm{Ha}$ in this study is accepted, meaning that the extrinsic motivation variable with its indicators has a significant effect on the tourist satisfaction variable.

The most significant indicator that plays a role is accommodation / lodging around Alas Harum Agrotourism with charming natural nuances (EM5) with a loading factor value of 0.919 and a p-value of 0.000 . The indicator that has a low significant value is a unique handicraft (EM8) with a loading factor value of 0.804 and a p-value of 0.000 . The results of this analysis support the research results of Wiranatha et. al (2018), that extrinsic motivation has a significant effect on the satisfaction of foreign tourists on sea-based tourism (diving) in Bali.

3. The effect of tourist satisfaction on revisit intention

The results of testing the third hypothesis indicate that the relationship between tourist satisfaction and revisit http://ojs.unud.ac.id/index.php/eot intention has a $\mathrm{P}$ value of 0,000 . $\mathrm{P}$ value $<0.05$, then $\mathrm{H} 0$ is rejected. These results indicate that tourist satisfaction has a positive and significant relationship to revisit intention. Thus $\mathrm{Ha}$ in this study is accepted, meaning that in this study the tourist satisfaction variable with its indicators significantly influences the revisit intention variable.

The most significant indicator that plays a role is satisfaction with the cleanliness of the tourist attraction of Alas Harum Agrotourism with a loading factor value of 0.929 and a $P$ value of 0.000 . The indicator that has the lowest significant value is the satisfaction with food and beverages served with a loading factor value of 0.828 and a $\mathrm{P}$ value of 0.000 . According to Porter in Hadiutama (2008), satisfaction is a feeling of happiness or disappointment after comparing perceptions with expectations. The results of this analysis support Alit's (2018) research, which states that tourist satisfaction has a significant effect on revisit intention. This proves that tourist satisfaction in agro-tourism is good so that it affects revisit intention.

\section{Contribution of Alas Harum Agrotourism to Communities and Farmers}

According to Astarhadi (1995), contributions can be made in various fields, namely thinking, leadership, 
professionalism, finance, and others. The contribution made by Alas Harum Agrotourism can be seen in the fulfillment of the raw materials used in Alas Harum in the presentation of food derived from local agricultural products. Alas Harum Agrotourism also employs a workforce that generally comes from local people. The number of local workers working at Alas Harum Agrotourism is currently 159 out of 163 total employees, which means that around $97.54 \%$ of the employees working at Alas Harum Agrotourism are local people and there are seven farmers who work in agro-tourism arrangements with a salary of Rp. 90,000 / day. Another impact can be seen from the number of tourists visiting Alas Harum to provide business opportunities for the community by providing products or services.

Alas Harum Agrotourism is also active in helping local community activities including religious or cultural activities in every village / banjar in the Tegallalang District area. Assistance was also given to several universities in Gianyar, such as Elizabeth University, which previously submitted a proposal request for funding assistance to Alas Harum Agrotourism. Alas Harum Agrotourism also provides financial assistance to the Tegallalang Village Head office to assist existing programs in Tegallalang Village, so that the

existence of Alas Harum Agrotourism has a very good impact on Tegallalang Village.

\section{CONCLUSIONS}

\section{Conclusions}

Based on the results and discussion that has been carried out in this study, it can be concluded; (1) the intrinsic and extrinsic motivation of tourists has a positive and significant influence on tourist satisfaction of Alas Harum Agrotourism, (2) tourist satisfaction has a positive and significant effect on the interest in returning to Alas Harum Agrotourism, (3) the contribution of Alas Harum Agrotourism to society and farmers. Its surroundings include employment, financial assistance provided to the Tegallalang Village office, financial assistance to villages / banjars in the Tegallalang District area, and assistance also given to several universities in Gianyar, one of which is Elizabeth University. In addition, the contribution made by Alas Harum Agrotourism can be seen in the fulfillment of the raw materials used in Alas Harum in serving food originating from local agricultural products of the local community.

\section{Suggestions}

Based on the results of the discussion and conclusions of this study, several suggestions can be proposed which are expected to be used as input for the 
management of Alas Harum Agrotourism, namely: (1) Further research is needed on the influence of tourist motivation on revisit intention to determine marketing strategies, (2) Unique handicrafts need to pay attention to the diversity of types, product quality, and product packaging in order to increase tourist satisfaction at Alas Harum Agrotourism which has an impact on improving the image of shopping.

\section{ACKNOWLEDGEMENT}

Thank you to all those who have supported and provided assistance in the form of data, thoughts, materials etc., so that this journal article can be completed properly. I hope that all the information written in it can be useful.

\section{REFERENCES}

Astarhadi. 1995. Kamus Besar Bahasa Indonesia. Jakarta: Rineka Cipta

Ghozali, I. 2014. Structural Equation Modeling, Metode Alternatif dengan. Partial Least Square (PLS). Semarang: Badan Penerbit Universitas Diponegoro. ISBN: 979.784.400.2

Hadiutama, Julianto. 2008. Hubungan antara Kepuasan Kerja dengan Loyalitas Karyawan (Studi Kasus terhadap Karyawan Universitas Sanata Dharma Yogyakarta) [skripsi]. (ID): Universitas Sanata Dharma. Yogyakarta. http://repository.usd.ac.id/f. (Diakses, 13 Juli 2019).
Purnami, N.N.A., dan I G.A.O., Suryawardani. 2018. Pengaruh kualitas layanan terhadap kepuasan wisatawan Agrowisata Bali Paulina untuk membentuk minat kunjungan ulangi. [skripsi]. (ID): Universitas Udayana. Bali

Santosa, Paulus Insap. 2018. Metode Penelitian Kuantitatif (Pengembanganan Hipotesis dan Pengujiannya Menggunakan SmartPLS). Yogyakarta: Andi.

Sugiyono. 2015. Metode Penelitian Kuantitatif Manajemen. Bandung: Alfabeta, Suryawardani, I G.AO., I K.G. Bendesa, M. Antara, D. Nursetyohadi dan A.S.

Wiranatha. 2016. International Journal of Applied Business and Economic

Research, Vol. 14, Number 12. (2016), page: 9377-940. Serals Publication PVT., LTD. New Delhi- India.

Suryawardani, I G.AO., A.S. Wiranatha, I K.G. Bendesa, M. Antara dan Gravari- Barbass. 2017. A Structural Model of Foreign Tourists' Loyalty in Nature- based Torism in Bali. International Journal of Applied Business and Economic Research, Vol. 15, Number 9. (2018), page: 195-215. ISSN: 0972-7302.

Sutjipta, I Nyoman. 2001. Agrowisata. (Diktat) Magister Manajemen Agribisnis. [thesis]. (ID): Universitas Udayana. Bali

Wiranatha, A.S., I G.A.O., Suryawardani, I K.G Bendesa dan M. Antara. 2018. Model of Foreign Tourist's Loyalty on Marine Tourism to Visit Bali. International Journal of Multidisciplinary Educational Research, Volume 5, Issue 3 (2), 2016. 